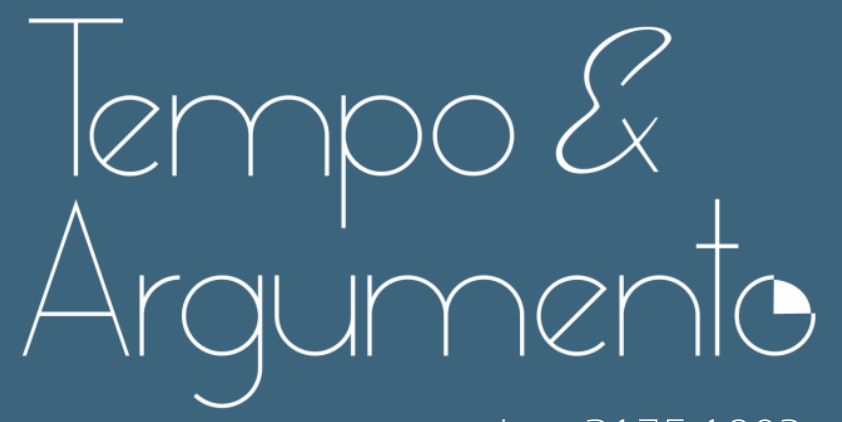

e-issn 2175-1803

Os dilemas da renovação na continuidade e o legado de Marcello Caetano: do outono ao inverno

- Pedro Emanuel Mendes

Doutor em Relações Internacionais pela Universidade Nova de Lisboa (UNL)

Investigador do Instituto Português de Relações Internacionais da Universidade Nova de Lisboa (IPRI-NOVA). Professor Auxiliar da Universidade Lusíada Porto (ULP).

Porto - PORTUGAL

novaresearch.unl.pt/en/persons/pedro-emanuel-mendes

pemanuelmendes@gmail.com

(iD) orcid.org/0000-0002-6321-8344

Para citar este artigo:

MENDES, Pedro Emanuel. Os dilemas da renovação na continuidade e o legado de Marcello Caetano: do outono ao inverno. Tempo e Argumento,

Florianópolis, v. 12, n. 29, e0205, jan./abr. 2020.

doi http://dx.doi.org/10.5965/2175180312292020e0205

Recebido: 25/06/2019

Aprovado: 09/12/2019 


\title{
Os dilemas da renovação na continuidade e o legado de Marcello Caetano: do outono ao inverno
}

\begin{abstract}
Resumo
Este artigo apresenta uma análise da liderança política de Marcello Caetano entre 1970 e 1974. Contextualiza as principais decisões de Marcello e desenvolve uma análise do período pós-primaveril do seu governo. O artigo centra-se nos dilemas de Marcello relativamente às oportunidades de mudança e de evolução do regime autoritário português e está dividido em duas partes. Na primeira, o outono marcelista, analisamos as suas tentativas de renovação na continuidade. $\mathrm{Na}$ segunda, o inverno marcelista, analisamos as causas e consequências da incapacidade crescente de Marcello gerir os constrangimentos e anacronismos do regime autoritário e imperial português.
\end{abstract}

Palavras-chave: Caetano, Marcello, 1906-1980. Portugal - Estado Novo. Autoritarismo. Elites.

\section{The dilemmas of renewal in continuity and the legacy of Marcello Caetano: from autumn to winter}

\begin{abstract}
This article presents an analysis of the political leadership of Marcello Caetano between 1970 and 1974. Contextualizes the main decisions of Marcello and develops an analysis of the post-spring period of his government. The article focuses on Marcello's dilemmas regarding the opportunities for change and evolution of the Portuguese authoritarian regime and is divided into two parts. In the first, the marcellist autumn, we analyze its attempts of renewal in continuity. In the second, the marcellist winter, we analyze the causes and consequences of the growing inability of Marcello to manage the constraints and anachronisms of the Portuguese authoritarian and imperial regime.
\end{abstract}

Keywords: Caetano, Marcello, 1906-1980. Portugal - New State. Authoritarianism. Elites. 


\section{Introdução}

Este artigo desenvolve uma narrativa analítica sobre o percurso político de Marcello Caetano durante os seus últimos quatro anos de governo (1970-1974). O seu objetivo é realizar uma análise dos dilemas de Marcello relativamente à continuidade e mudança das suas opções e apresentar um balanço do seu legado. O artigo centra-se na contextualização ideacional do ambiente político do regime autoritário português e na avaliação das principais decisões de Marcello face às (im)possibilidades de evolução democrática. Com base em discursos e publicações oficiais, o artigo cruza fontes primárias e secundarias do consulado de Marcello e lança novas pistas para o debate relativo às causas do insucesso da sua ideia principal: "a renovação na continuidade" (CAETANO, 1971).

No início do seu governo (1968-1970), existiu a esperança da primavera marcelista e o início de uma liberalização do regime autoritário e imperial do Estado Novo português, porém, a partir de 1970, entra-se na sua frustração, o outono marcelista. Na passagem de 1972 para 1973, inicia-se o inverno marcelista que conduziu à implosão do Estado Novo e à posterior explosão do verão quente da transição democrática portuguesa em 1975.

Neste quadro, este artigo concilia a narrativa histórica com uma interpretação político-sociológica sobre as principais decisões de Marcello relativamente às oportunidades de mudança do regime autoritário português. Apresenta uma análise do período pós-primaveril do governo de Marcello e avança com uma interpretação das hesitações, frustrações e angústias do seu caminho descendente face à sua inicial abertura política.

O artigo está dividido em duas partes. Na primeira, que designamos de outono marcelista, analisamos as suas tentativas de renovação na continuidade. $\mathrm{Na}$ segunda, que designamos de inverno marcelista, analisamos as causas e consequências da incapacidade crescente do regime, e do seu chefe de governo, em gerir as pressões, internas e externas, a que foi sujeito entre 1972 e 1974.

\footnotetext{
A liberalização é o processo identificado com medidas tomadas por um regime autoritário no sentido de providenciar maiores garantias de direitos aos indivíduos e aos grupos de uma sociedade (O'DONNELL; SCHMITTER, 1986 p. 6-9). A liberalização pode ser vista com um sinal para o início de uma possível transição democrática, mas não deve ser confundida com um processo de democratização (MENDES, 2004), como aliás, este trabalho demonstra.
} 
O artigo procura introduzir alguma imaginação sociológica relativamente aos projetos de escrever a história de Marcello Caetano ${ }^{2}$, bem como à sua própria tentativa de escrever a história do seu governo. ${ }^{3}$ Tenta propor novas avenidas interpretativas sobre a liderança de Marcello como chefe de governo e apresenta uma argumentação que distingue a análise técnica da análise política do seu legado.

\section{O outono marcelista: sinais de frustração (1970-1971)}

Marco fundamental da primavera política marcelista, as eleições de 1969 foram simultaneamente um sinal de esperança e de frustração. Por um lado, existiu uma campanha eleitoral relativamente concorrencial. Por outro, os resultados foram os mesmos das eleições anteriores, isto é, a negação de participação política efetiva aos membros da oposição. Neste contexto, a grande oportunidade política perdida de Marcello foi a negação da criação de partidos políticos, principal condicionamento para uma transição democrática.

Importa também sublinhar que a oposição comunista (CDE) teve mais peso do que a oposição republicana moderada (CEUD). O que solidificou a perceção de Marcello sobre o perigo comunista e a ineficácia política da oposição de esquerda não comunista. Esta perceção terá contribuído para que a abertura política inicial retroceda com o argumento da impossibilidade de construir pontes com a oposição revolucionária. Para Marcello a ideologia comunista era a verdadeira ameaça à ordem social e política em Portugal. Ao contrário da burguesia liberal e socialista, "a única ideologia da oposição que tem uma organização com sequazes militantes é a comunista” (CAETANO, 1973, p. 24). Apesar da sua antipatia de estimação por Mário Soares, é o Partido Comunista Português (PCP) e a sua expansão que serão o alvo preferencial do regime.

\footnotetext{
2 Muitas das melhores ideias sobre Marcello não são novas (LUCENA, 1976; ROSAS, 1994; 1999; VALENTE, 2002; TORGAL, 2009), mas recentemente surgiram novos trabalhos (CRUZ; RAMOS, 2012; CASTILHO, 2012; LEITÃO, 2014) que ajudam a construir uma visão histórica mais ampla sobre Marcelo.

${ }^{3}$ Muitos políticos gostam de escrever a sua inside story, invariavelmente justificativa. Nos regimes autoritários esta tentação é ainda maior. Marcello, que também foi um historiador, não foge à regra, bem pelo contrário.
} 
Embora já sem o ânimo inicial, Marcello continua convencido de que, após as eleições de 1969, é necessário encetar uma reorganização do sistema político. Para tal, vai formar um novo governo, tentar trabalhar com os novos deputados da Assembleia Nacional, bem como refundar o velho partido do regime (MENDES, 2020a).

Relativamente à Assembleia Nacional, a situação revelou-se complexa. Apesar da renovação formal, existia uma maioria considerável de deputados que mantinha relações diretas e indiretas com o velho regime do Estado Novo. Conquanto existissem diferentes sensibilidades, o parlamento continuava esmagadoramente conservador e antidemocrático. A exceção eram os recémeleitos deputados independentes, a Ala Liberal.

Estes deputados aceitaram o convite de Marcello Caetano para se candidatarem nas listas da União Nacional, mas não estavam ligados ao aparelho político do Estado Novo. Relativamente jovens e politicamente inexperientes, acreditavam na evolução interna do regime. Tinham uma noção clara do anacronismo do autoritarismo corporativo do Estado Novo e da necessidade de ultrapassar o anquilosamento do regime através de uma liberalização que possibilitasse uma transição democrática. A Ala Liberal tinha sido originalmente animada por Melo e Castro e inseria-se no projeto de liberalização controlada que Marcello queria desenvolver (MENDES, 2020a). Isto significa que inicialmente existia uma aparente convergência política entre a Ala Liberal e Marcello Caetano. Todavia, após o início da sessão legislativa, começou a ficar evidente a incompatibilidade entre o projeto de liberalização controlada de Marcello e o projeto de liberalização democrática dos deputados da Ala Liberal. ${ }^{4}$

Os deputados da Ala Liberal desejavam reformas políticas e avanços rápidos na liberalização. Marcello queria uma liberalização controlada e com limites. À medida que o tempo foi avançando, estas divergências foram aumentando e determinaram uma relação de desencanto e frustração entre Marcello e a Ala Liberal. Para além das diferentes conceções sobre a celeridade

\footnotetext{
${ }^{4}$ A Ala Liberal, composta por cerca de vinte deputados, manteve-se ativa de 1969 até 1973 e pretendia ser, uma terceira via que "entre a situação e a oposição conseguisse propor e executar um programa que levasse Portugal à Democracia” (BALSEMÃO, 2012, p. 171).
} 
Os dilemas da renovação na continuidade e o legado de Marcello Caetano: do outono ao inverno Pedro Emanuel Mendes

e a substância das reformas políticas, a rutura política foi acelerada pelo precoce desaparecimento do seu líder natural, José Pedro Pinto Leite, bem como do seu mentor, Melo e Castro. Ambos tinham relações de amizade com Marcello e foram elementos decisivos na socialização ideacional de Marcello sobre a necessidade de reformas políticas liberais. O seu desaparecimento significou que Marcello ficou mais suscetível à socialização das ideias conservadoras e antiliberais. $^{5}$

Na ótica do chefe de governo, este grupo de deputados existia para o apoiar. Por sua vez, a Ala Liberal acreditava que a sua função era a de propor propostas para a mudança do regime rumo à democracia. Marcello nunca compreendeu bem esta diferença de rumos e em momentos decisivos, onde a Ala Liberal tentou iniciar um rumo democrático, Marcello não os acompanhou. Isto significa que a partir de 1970 foram visíveis as dificuldades crescentes relativamente à conciliação entre as ideias de evolução democrática e as de continuidade autoritária. Estas dificuldades ficaram bem expressas nos debates entre os continuístas e os reformistas na Assembleia Nacional (MENDES, 2012; 2013). ${ }^{6}$

\footnotetext{
Este argumento reflete a lógica do Portugal autoritário, elitista e rural-conservador, e interliga-se com o argumento de que não existiu uma verdadeira pressão da sociedade portuguesa que obrigasse Marcello a mudar (RAMOS, 2012, p. 479). Por outro lado, justifica o argumento clássico que uma vez corporativista autoritário nunca mais um democrata. Este argumento relativo à sua estrutural visão autoritária é muito comum na literatura histórica sobre Marcelo Caetano (LUCENA, 1976; VALENTE, 2002; TORGAL, 2009) e é utilizado para afirmar que o Marcelismo não significou uma mudança face ao Salazarismo. Nós concordamos com o argumento que Marcello não era um democrata e que é importante termos em consideração o seu passado ligado à construção do Estado Novo, já para não falar do fervor ideológico autoritário da sua juventude (MENDES, 2020a; CASTILHO, 2012; LEITÃO, 2014). Todavia, o Marcelismo não é o Salazarismo. Por um lado, como aqui se identifica, o contexto histórico de afirmação e construção do Estado Novo salazarista é diferente (anos trinta, quarenta, cinquenta...), e menos complexo, do que o contexto histórico do consulado Marcelista (finas dos anos sessenta, inícios dos anos setenta). Por outro lado, são duas personalidades políticas diferentes e com visões do mundo distintas, embora ambos autoritários e corporativistas. Finalmente, importa, como aqui se pretende, ter uma leitura sofisticada e distanciada da visão, muitas vezes mais política do que histórica, dos atores (políticos e académicos) que ativamente sofreram com as ilusões de mudança e com as frustrações da continuidade do Marcelismo. Isto significa que, uma coisa é perceber que os atores políticos da oposição da época, sobretudo o PCP e o próprio Mário Soares, naturalmente sublinham que o Marcelismo é a continuidade do Estado Novo autoritário, e nada mudou de substancial, leia-se fim do autoritarismo. Outra coisa é uma leitura histórica mais pormenorizada, onde se percebe que existiram ciclos diferenciados durante o próprio Marcelismo e janelas de oportunidades de mudança que não foram aproveitadas.

${ }^{6}$ Por exemplo, os debates sobre: os custos económicos e políticos da guerra colonial; a situação dos presos políticos; a nova política industrial; as prioridades da política externa portuguesa; ou a abolição da censura. Marcello assistia a estas discussões com relativo desagrado, pois nenhum dos dois polos na discussão era verdadeiramente o seu (MENDES, 2103).
} 
A gradual separação política entre a Ala Liberal e Marcello foi patente na discussão sobre a revisão constitucional, onde os deputados independentes apresentaram uma proposta alternativa. Na opinião de Marcello esta postura foi uma "tática errada", pois não colaboraram com o seu desejo de uma "progressiva liberalização" e "em vez disso optaram pela oposição sistemática, sob o pretexto de que aquilo que o governo propunha não era bastante" (CAETANO, 1974, p. 65).

A partir de 1970, o caminho de abertura política começou a ser invertido. Facto paradigmático desta inversão ocorreu no dia 30 de Abril, com a formalização da acusação da Direção Geral de Segurança (DGS) a Mário Soares por crimes políticos. ${ }^{7}$ Da mesma forma que a permissão do seu regresso foi uma medida simbólica do clima de abertura e das possibilidades da primavera marcelista, o seu exílio marca simbolicamente o fim da abertura.

No segundo aniversário da sua tomada de posse, Marcello faz um balanço dos dois anos de governo onde sublinha que "a reforma da sociedade portuguesa tem de ser feita em paz" (CAETANO, 1972a). Todavia, a paz social e política em Portugal estava cada vez mais frágil, uma vez que para além da oposição do PCP, começam a surgir novos grupos radicais de esquerda e o próprio PCP inicia uma estratégia de radicalização violenta. ${ }^{8}$ Apesar da expressão política desta radicalização ter um significado pequeno, e ser mais simbólica do que propriamente uma ofensiva real ao poder do Estado Novo, Marcello encara-a como uma grande ameaça à ordem, uma das ideias basilares do seu pensamento. Esta perceção aumenta o seu sentimento de desconfiança maniqueísta pela oposição e perigo do avanço comunista.

A sua resposta política enquadra-se na reação clássica dos regimes autoritários quando confrontados com pressões políticas: cerra fileiras no combate ao inimigo e contra-ataca com uma nova onda de repressão e prisões políticas à oposição. Todavia, esta atitude não vai diminuir a crescente dinamização da atividade oposicionista do PCP e dos emergentes grupos de esquerda radical, bem pelo contrário.

\footnotetext{
Marcello nunca perdoou a Soares as suas intervenções, onde expunha que a mudança marcelista não significava nenhuma mudança substancial do regime autoritário e que a guerra colonial era uma "guerra sem sentido nem saída" (SOARES, 1975, p. 31).

${ }^{8}$ Por exemplo, em 18 de setembro surge o Movimento Reorganizativo do Partido do Proletariado (MRPP) e no dia 26 de outubro dá-se o primeiro ataque bombista da Ação Revolucionária Armada (ARA), braço armado do PCP.
} 
Na Assembleia Nacional, o ano de 1970 encerra com a questão da revisão constitucional. No dia 2 de dezembro é apresentado o projeto do governo e no dia 16 o projeto alternativo da Ala Liberal, liderado por Sá Carneiro. Este projeto põe a tónica nos direitos cívicos, introduz o fim dos poderes discricionários da polícia política e reintroduz a eleição direta do Presidente da República, que tinha sido eliminada na revisão constitucional de 1959, em consequência do susto político que representou para o regime do Estado Novo a candidatura do general Humberto Delgado. O debate sobre os projetos inicia-se em março de 1971 e terá o seu epílogo em julho. A forma como o governo impossibilitou o debate e conseguiu anular administrativamente o projeto da Ala Liberal foi paradigmático da cultura política do regime. ${ }^{9}$ Este foi o segundo grande teste de fogo para Marcello. Aqui se colocaram as questões essenciais relativas ao caminho a seguir na renovação do regime e às (im)possibilidades de uma evolução democrática.

Como sublinha Jorge Miranda, "o momento de viragem do regime para a não evolução é a revisão constitucional e é o impedir da discussão da votação na especialidade dos projetos apresentados" (PEREIRA; MIRANDA; TELES, 2012, p. 191). Foi neste momento que se estabeleceu um corte político entre a Ala Liberal e o governo. Marcello confirma que a partir de 1971 a "Assembleia Nacional ficou cindida" (CAETANO, 1974, p. 66). Na sua opinião, isto deveu-se a nunca ter encontrado "apoio seguro nos liberais", o que o forçou a "procurar esse apoio na maioria conservadora da Assembleia, facto da maior importância de que os liberais foram os únicos responsáveis" (CAETANO, 1974, p. 66, grifo original).

Apesar de ter conseguido fazer aprovar a sua proposta de revisão constitucional, ${ }^{10}$ Marcello sai fragilizado. O desfecho da revisão, sobretudo a recusa do sufrágio direto da eleição presidencial, que contraria a própria opinião de Marcello, defendida em parecer da Câmara Corporativa em 1951, frustrou todos os que acreditavam nos propósitos de Marcello em mudar o regime. Muitos marcelistas e seus amigos próximos, como André Gonçalves Pereira, acreditam

\footnotetext{
9 Confrontado com a eventualidade de discussão na Assembleia do projeto da Ala Liberal, o governo constitui uma Comissão Eventual para a Revisão Constitucional. Depois fez aprovar que a discussão e votação na especialidade se realizassem sobre o seu parecer. Finalmente, o projeto foi rejeitado na generalidade na Câmara Corporativa.

10 A revisão constitucional é finalmente aprovada a 7 de julho e convertida em lei no dia 16 de agosto de 1971. A nova lei orgânica do ultramar português é aprovada em 23 de junho de 1972 e, no dia 22 de dezembro, são aprovados os novos estatutos político-administrativos das províncias ultramarinas, que passam a ser "regiões autónomas".
} 
que esta "foi uma ocasião perdida" (PEREIRA; MIRANDA; TELLES, 2012), nomeadamente para o próprio Marcello se candidatar à presidência da república. Marcello recusou as duas hipóteses provavelmente por acreditar que não tinha poder para conseguir impor essas soluções, o que demonstra a incapacidade de se libertar do aprisionamento político da ala conservadora. A questão presidencial foi um ponto fulcral da evolução do regime, "o problema da eleição direta foi decisivo, matou o regime," (PEREIRA; MIRANDA; TELLES, 2012, p. 193).

No dia 27 de setembro, terceiro aniversário da sua posse, Marcello discursa no Palácio de São Bento e explica que "temos grandes dificuldades a vencer" e “que não estamos em tempos fáceis" (CAETANO, 1972a, p. 3-4). Destaca que o grande desafio da ação governativa tem sido a capacidade de conseguir conciliar o "esforço de defesa" com o "esforço de fomento", pelo que era necessária uma "gestão cuidadíssima dos dinheiros públicos" para que o governo continuasse a apoiar as Forças Armadas e a adotar uma política de investimento e desenvolvimento que não deixe "que o país se distancie mais dos padrões de desenvolvimento da Europa" (CAETANO, 1972a, p. 4). Esta será outra ideia-chave da ação política de Marcello, que sintetiza na fórmula política: Progresso em Paz.

Para Marcello esta ideia era não só uma "aspiração", mas uma "efetiva realização" do seu governo e do povo português (CAETANO, 1972a, p. IX-X). Na sua ótica, os únicos caminhos para atingir os objetivos do progresso "são os do entendimento e da paz" (CAETANO, 1972a, p. IX-X). Mas existiam perigos que surgiam dos "apóstolos da revolução" e da "destruição radical do que está"; por isso, sublinha, "importa a luta quotidiana contra os diversos terrorismos que vicejam por esse mundo além" (CAETANO, 1972a, p. IX-X).

No dia 5 de novembro é promulgada a lei da imprensa (n. 05/71) e a censura passa a designar-se "exame prévio". Esta lei, que vigorará até abril de 1974, pretendeu atenuar o papel da censura através de uma delimitação mais específica dos temas sujeitos ao controlo da liberdade de imprensa. Na prática, o exame prévio continuou a ser um instrumento de controlo do Estado, nomeadamente face ao que regime designava como "ameaças à Constituição e à independência e prestígio do Estado". O argumento utilizado reflete uma ideia clássica do conservadorismo jurídico de Marcello, muito típica, aliás, da cultura 
política e da semântica legalista do Estado Novo. A liberdade tem de ser controlada a favor da existência da própria liberdade. ${ }^{11}$

Em 16 novembro, na Conversa em Família "Planeamos e Cumprimos", Marcello faz um balanço do seu governo. Num tom naturalmente apologético, o Presidente do Conselho sublinha as reformas lançadas na administração pública, nomeadamente: a reorganização orgânica dos Ministérios da Educação Nacional, da Saúde e Assistência, das Comunicações, bem como da Inspeção-Geral das Atividades Económicas. Ressalta também as reformas no Urbanismo e Habitação onde, após a lei dos solos, de 24 de novembro de 1970, foi aprovado um programa de investimento, inserido no III Plano de Fomento, de mais de cinco milhões de contos na construção de casas económicas e aquisição de terrenos em Lisboa e Porto (PORTUGAL, 1970; 1971).

Com efeito, no quadro do segundo triénio do III Plano de Fomento (19711973), iniciam-se investimentos decisivos para o desenvolvimento de Portugal, designadamente: no Turismo; na expansão da eletrificação nacional; na ampliação da refinaria de petróleo do Porto; no lançamento do projeto de Sines; na renovação da rede geral da CP; na aquisição de navios mercantes e novos aviões para a TAP; no início da construção de autoestradas em regime de concessão; no alargamento acelerado da instalação telefónica; no desenvolvimento do metro de Lisboa e dos portos de Lisboa, Douro e Leixões (CAETANO, 1972a; PORTUGAL, 1972). Finalmente, utilizando de forma eficaz "o paradoxo da verdade" (MENDES, 2019) Marcello sublinha o "progresso galopante no ultramar"; a importância do novo sistema de pagamentos interterritoriais no espaço português e a reforma do regime de transferências de moeda entre o ultramar e a metrópole que permitiu resolver o problema dos "atrasados", a dívida acumulada das colónias (CAETANO, 1974, p. 37-44; PORTUGAL, 1972).

\section{O inverno marcelista: sinais de angústia (1972-1974)}

Marcello inicia o ano de 1972 com um discurso na conferência anual da ANP, intitulado "Pela Segurança, Bem-Estar e Progresso do Povo Português" (CAETANO, 1972b). Aqui sintetiza o pensamento e ação política dos três anos de

\footnotetext{
11 Nas suas palavras: "A liberdade tem de ser exercida dentro das leis e conforme as leis. Não há liberdade contra a lei” (CAETANO, 1970, p. 131).
} 
governo nas seguintes ideias-chave: a "defesa do ultramar"; a "batalha da educação"; o "incremento da obra de fomento económico"; o "Estado-Social12 mas não socialista"; "a validade da doutrina corporativista"; e "a subsistência da empresa privada" (CAETANO, 1972b).

Marcello explica que as suas reformas têm de ser prudentes, uma vez que não defende "uma liberalização imediata e tão ampla que deixasse caminho aberto à revolução” (CAETANO, 1972a). Acredita que o caminho tem de ser o da "prudência" e o da "segurança sem catástrofe", ou seja, um caminho que se enquadra na sua fórmula de Progresso em Paz (CAETANO, 1972a). Na prática, significa a defesa da continuidade autoritária e a impossibilidade de caminhar para uma democratização, pois isso conduziria à legalização dos partidos marxistas o que, na sua ótica, levaria "a instaurar a imoralidade, a indisciplina, o crime, a desordem, a luta de classes, a guerra civil” (CAETANO, 1972a, p. 99).

Por detrás deste seu permanente receio de abrir o regime estavam duas razões, uma estrutural e outra conjuntural. A primeira dizia respeito à sua personalidade e cultura política não democrática e à sua convicção de que Portugal não tinha condições para se tornar uma democracia. A segunda prendiase com o problema ultramarino, designadamente a crescente dificuldade de legitimar interna e internacionalmente a continuidade da guerra colonial.

Apesar das dificuldades, Portugal partira para a Guerra num contexto doméstico e externo, relativamente favorável, quer de um ponto de vista de legitimação normativa quer de um ponto de vista estratégico-militar. Passados mais de dez anos, esse contexto mudara radicalmente. Quer ao nível internacional quer ao nível interno, as três frentes da guerra em África tinham cada vez menos apoios. De um ponto de vista económico, o esforço de guerra já representava perto de $40 \%$ do orçamento geral do Estado. Mesmo ao nível das chefias militares começava-se a ter consciência que a guerra não tinha solução militar. Esta ideia era mais presente na Guiné, onde, em 1972, a situação militar não parava de se deteriorar.

\footnotetext{
12 Esta é outra ideia típica do Marcelismo e reflete-se no desenvolvimento de políticas sociais e de Estado-providência. Vários autores encontram aqui uma das suas marcas distintivas (CASTILHO, 2012; CRUZ, 2012; LEITÃO, 2014). Outros sublinham que o Estado Social foi apenas uma nova designação para Estado Novo, que se inseria numa estratégia política de refrescamento das ideias gastas da década de trinta (TORGAL, 2009). Como este trabalho demonstra ambas as teses se verificam.
} 
Consciente destas dificuldades, o governador e comandante-chefe da Guiné, António Spínola, propõe-se iniciar negociações políticas com o líder do PAIGC, Amílcar Cabral, através da mediação do presidente do Senegal, Leopold Senghor. ${ }^{13}$ Após um encontro com Senghor, no Senegal, Spínola viaja para Lisboa e apresenta a sua ideia de uma solução política a Marcello e ao ministro do ultramar no dia 26 de maio.

Marcello prontamente discordou de Spínola relativamente à necessidade de prosseguir com as conversações. De acordo com a sua visão política e legalista, Portugal não poderia negociar com Amílcar Cabral pois isso seria reconhecer o PAIGC como uma "força beligerante" possuidora de "importante domínio territorial” (CAETANO, 1974, p. 190-191), o que equivaleria a destruir toda a argumentação jurídico-política de Portugal sobre a defesa do ultramar. Por outro lado, Marcello argumenta que após a definição do cessar-fogo era inevitável um acordo final, o que criaria um precedente relativamente às restantes regiões ultramarinas. Neste quadro, Marcello é perentório: "Para a defesa global do ultramar é preferível sair da Guiné por uma derrota militar com honra, do que por um acordo negociado com terroristas, abrindo caminho a outras negociações" (CAETANO, 1974, p. 191). ${ }^{14}$ Deste modo, também na questão central do ultramar, quando se vê confrontado entre continuar ou alterar as opções políticas de fundo, Marcello escolheu a continuidade.

Outra escolha decisiva que teria de ser feita em 1972 era a relativa à presidência da república. Américo Tomás tinha 78 anos e estava há catorze anos na presidência (eleito em 1958 e reeleito em 1965). Após o desaparecimento de Salazar, Américo Tomás passou a ser o líder que congregava a ala mais

\footnotetext{
13 O plano de Spínola passava por um cessar-fogo, a integração das forças militares do PAIGC em Unidades Africanas das Forças Armadas Portuguesas e a nomeação de Amílcar Cabral como secretário-geral da província, em simultâneo com o secretário-geral em exercício. A ideia apadrinhada por Senghor e com apoio de Amílcar Cabral, seria a da entrada da Guiné numa fase de autonomia interna por um período não inferior a dez anos. Seguia-se uma consulta popular que possibilitaria uma independência no quadro de uma comunidade luso-africana.

${ }^{14}$ Em 25 de junho Marcello convoca o Conselho Superior de Defesa Nacional e é discutido o problema da Guiné e a visão do general Spínola. Todos os presentes - Presidente da República, ministro da Defesa Nacional (Sá Viana Rebelo), ministro dos Negócios Estrangeiros (Rui Patrício), ministro do Ultramar (Silva Cunha) e CEMGFA (Venâncio Deslandes) - corroboraram a visão de Marcello e "concluíram não haver razão suficiente para seguir as sugestões do Presidente do Senegal, que o Comandante-Chefe da Guiné defendia” (CUNHA, 1977, p. 51).
} 
conservadora do regime. Por outro lado, o presidente da república tinha um poder político importante, tornando o sistema de poder relativamente bipolar.

Nesta conjuntura, a eleição presidencial revestia-se de uma importância política decisiva. Os reformistas do regime queriam um novo candidato presidencial e os mais próximos de Marcello gostariam que fosse ele o candidato. Já os conservadores apoiavam uma recandidatura de Américo Tomás. Marcello viu-se novamente no dilema de optar entre a continuidade e a mudança. Apesar de chegar a ponderar os prós e os contras da sua candidatura a Belém, concluiu que face à complexidade da situação não seria ele a contrariar a opção de Américo Tomás se recandidatar. A maioria dos seus próximos alertou-o para os inconvenientes dessa recandidatura, mas a sua mente legalista, aliada à sua lealdade política, pesou mais. Marcello escudou-se nos preceitos constitucionais e argumentou que o presidente do conselho exercia o seu governo por um ato de confiança do presidente da república. Em sua opinião, não "seria correto nem leal que o presidente do conselho dissesse ao chefe de Estado que saísse do seu lugar" (CAETANO, 1974, p. 82).

No dia 25 de julho de 1972, Américo Tomás é reeleito através do colégio eleitoral. Com a reeleição de Américo Tomás, o regime fecha definitivamente a porta a uma evolução e Marcello perde a última oportunidade para tentar desbloquear o regime. Toda a oposição reage mal à reeleição de Tomás e muitos marcelistas reformistas não aceitaram bem a indisponibilidade de Marcello em se candidatar à presidência e abrir a possibilidade de um novo ciclo político.

Claro que as opções de Marcello não podem ser desligadas da sua circunstância política, ou seja, não devem ser interpretadas apenas como resultado das suas preferências, mas também como consequência dos constrangimentos e equilíbrios políticos que teve de considerar. Ele próprio consente que a solução da reeleição de Tomás era a mais cómoda para preservar o seu papel político. As hipóteses, sondadas pelos liberais, dos generais Spínola ou Kaulza de Arriaga, seriam, na sua lógica de prudência conservadora, potencialmente mais incómodas do que a do velho almirante. Isto significa que repetidas vezes as suas aparentes ambiguidades políticas resultam também da sua tentativa de sobrevivência política, nomeadamente da manutenção de 
equilíbrios entre as várias correntes políticas do Estado Novo. Aqui o resultado não foi completamente insatisfatório.

A sua notória incapacidade foi a de lidar com os movimentos políticos que não se integravam ou reviam no Estado Novo. Marcello nunca conseguiu dialogar politicamente com quem se opunha à manutenção do regime autoritário. Esta impossibilidade gerou uma cultura política de combate maniqueísta que fomentou o extremar de posições. A partir de 1970, progressivamente, o poder situacionista começou a socializar um ambiente político de resistência contra os inimigos internos e externos. Este ambiente político de cerco vai complexificarse com a crescente radicalização da esquerda e com o surgimento de uma nova direita radical nacionalista, que era igualmente corrosiva para com as políticas do marcelismo. Sem surpresa, Marcello solidifica um discurso maniqueísta. De um lado, os que apoiam a ordem estabelecida, do outro, os que defendem a revolução "fomentadora de anarquia e criadora da miséria". Na sua ótica, "o dilema do problema político português" resume-se na escolha entre "o regime constitucional vigente, onde a propriedade garante a liberdade, ou um socialismo sem face humana que visará suprimir a propriedade individual e, de uma forma ou outra, reduzir os homens à condição de servos da coletividade" (CAETANO, 1972a, p. 164).

Nas universidades começam a disseminar-se os Comités de Luta Anticolonial (CLAC) ligados a grupos de inspiração marxista-leninista e maoísta. Depois de em 1971 o Ministério da Educação Nacional ter determinado o estado de exceção nas universidades, o ano de 1972 é particularmente agitado. As causas da agitação radicam na intensificação do ativismo contra a guerra colonial e reforma do ensino anunciada. Várias faculdades das Universidades de Lisboa e Coimbra organizam manifestações de protesto e boicotam a realização de exames. Como resposta à contestação, o governo impõe o uso da força, sucedem-se as invasões policiais, é encerrada a maioria das associações de estudantes e dezenas de alunos são presos ou incorporados coercivamente nas Forças Armadas. 
Também no mundo católico se assistirá à crescente contestação da guerra, sobretudo nos núcleos de católicos progressistas. Até mesmo a nova hierarquia da Igreja, com o cardeal-patriarca D. António Ribeiro, começa a adotar uma atitude de distanciamento relativamente à política colonial do governo. Exemplo deste ambiente antiguerra que se estava a instalar em Portugal é a realização da "vigília para a paz", na capela do Rato. Esta vigília, e sobretudo a reação do governo, tiveram uma grande repercussão política. ${ }^{15}$

Paradoxalmente, de um ponto de vista da ação governativa interna, o ano de 1972 é marcado por sucessos e medidas importantes. Com destaque para o plano de expansão e diversificação do ensino superior protagonizado pelo ministro Veiga Simão. A criação de novas instituições de ensino superior foi um projeto ambicioso que se inseria no contexto da modernização da sociedade portuguesa. Outro exemplo emblemático foi a concessão aos servidores do Estado, civis e militares, de um suplemento eventual de ordenado ou pensão, o 13.ำ mês (decreto-lei n.o 483/72). Destaque ainda para a Lei do Fomento Industrial, de 27 de maio de 1972, que institui o novo enquadramento legal do exercício da indústria, designadamente o início do fim do condicionamento industrial, a modernização do parque industrial e a desmultiplicação dos centros de decisão económica (PORTUGAL, 1972; 1973).

Todavia, estes sucessos relativos na frente interna não ocultavam as crescentes dificuldades do governo de Marcello na frente externa. Em 22 de Setembro, a Assembleia Geral da ONU aprova, por 79 votos a favor, 10 contra e 16 abstenções, a atribuição do estatuto de observador aos representantes dos movimentos de libertação das colónias portuguesas. No dia 3 de outubro o ministro dos Negócios Estrangeiros, Rui Patrício, reage violentamente, levando a maioria dos delegados a abandonar a sala em protesto contra o seu discurso. Este episódio em que o ministro português foi deixado a falar sozinho espelha o clima de isolamento normativo que Portugal vivia (MENDES, 2018).

\footnotetext{
15 Na missa de 30 de dezembro alguns católicos iniciaram uma vigília para celebrar o Dia Mundial da Paz e alertar "as consciências para a guerra colonial", até ao dia 1 de janeiro de 1973. No dia 31, o governo enviou a polícia e ordenou a saída dos participantes. Estes não obedeceram e a PSP e a DGS invadiram a capela. Foram presas quinze pessoas. Os funcionários públicos foram demitidos em 9 de janeiro, ao abrigo do decreto-lei n.․ 25317 de 1935, decalcando uma decisão de Salazar de 1947, contra a qual, na altura, Marcello foi contra.
} 
Em novembro, a Assembleia Geral aprova duas resoluções sobre os territórios não autónomos portugueses, a resolução n.ํ 2908 (XXVII), de 2 novembro, e a resolução n. 2918 (XXVII), de 14 de novembro. Finalmente, no dia 22, o Conselho de Segurança da ONU aprova por unanimidade a resolução (S/322) que exorta Portugal a proceder a uma solução política e ao consequente desenvolvimento de processos de autodeterminação (MENDES, 2020b).

Com esta resolução, o conflito político-diplomático que Portugal travava com a ONU relativamente aos "territórios não autónomos" é manifestamente perdido. São contrariadas as ideias fundamentais dos argumentos do Estado Novo: o não reconhecimento do carácter unitário e pluricontinental de Portugal e a consequente necessidade de adotar o princípio da autodeterminação.

Apesar das críticas que os integracionistas conservadores apontam a Marcello relativamente às hesitações, ambiguidades e flutuações em matéria de política externa, a verdade é que, na sua essência, Marcello manteve de forma coerente durante o seu governo as ideias fundamentais sobre a defesa do ultramar. Claro que a coerência no erro não o elimina. Pelo contrário, em política a coerência no erro acaba inevitavelmente por exponenciar consequências indesejáveis. O que claramente aconteceu neste caso.

Em abono de Marcello pode, contudo, chamar-se a atenção de que a sua ação não foi apenas de resistência imobilista. Em teoria, Marcello tinha uma visão africanista que, sustentada na sua política de fomento ultramarino, preconizava uma solução portuguesa para o problema colonial. Esta solução, de médio prazo, era uma autonomia participada neo-federal que passaria pela interligação pacífica entre uma portugalização do sistema político, jurídico e económico e uma africanização dos recursos humanos, administrativos e militares (MENDES, 2020a). Na prática, esta visão esbarrava na convicção de Marcello em não negociar com os movimentos de libertação e aproximava-o mais das ideias de proporcionar "independências brancas", o que, como se provou, era inviável (MENDES, 2020b).

Marcello iniciará o ano de 1973 a explicar na RTP, em 15 de janeiro, as soluções do seu governo para a questão ultramarina. Na sua ótica, 
o governo não está inativo na busca de soluções políticas que sejam válidas para os territórios do ultramar. Soluções nossas, e não impostas por outros, soluções na linha que um dia defini como sendo a de preparar o futuro para que seja um futuro português. (CAETANO, 1973, p. 13).

Em finais de janeiro de 1973, Sá Carneiro, incomodado com o boicote político da ala conservadora às suas propostas, renuncia ao seu mandato. No dia 6 de fevereiro, a propósito de um debate sobre a censura, o ambiente de crispação política na Assembleia Nacional atinge o rubro, com Miller Guerra no final da sua intervenção a pedir a renúncia do seu mandato. O jornal britânico The Daily Telegraph publica no dia 8 de fevereiro o seguinte texto:

Ontem, o Dr. Miller Guerra, um médico proeminente, resignou. A semana passada o Dr. Francisco Sá Carneiro, um jovem advogado do Porto, que era considerado o líder do grupo, deixou o Parlamento dizendo que seria inútil permanecer nele. Observadores políticos são da opinião que o desalojamento dos liberais do Parlamento, sem o mínimo sinal de discordância do Dr. Caetano, significa que o Governo deliberadamente se desembaraçou do grupo e está agora firmemente decidido a segurar a ala de direita, os "ultras". (CARNEIRO, 2010, p.15)

Marcello, sempre preocupado em manter uma certa equipendência entre as sensibilidades políticas, vai tentar minimizar os riscos de ver ruir o equilíbrio cada vez mais difícil do seu governo. Não querendo alienar nenhum dos seus apoios políticos, no dia 15 de fevereiro, através de Mota Amaral, reuniu em almoço com alguns dos deputados que restavam da Ala Liberal. Também irá escrever uma carta, em 26 de fevereiro, a Spínola para tentar minimizar a distância política e pessoal que se estava a cavar com o governador da Guiné. ${ }^{16}$ Eram tentativas de controlo de danos. Todavia, os danos começavam a ficar descontrolados e o ano de 1973, o annus horribilis do governo, será o princípio do fim.

Ao nível económico, o ano de 1973 interrompe um período de crescimento e de estabilidade dos preços. À questão da inflação, que atinge os 11,7\% relativamente a 1969, irão somar-se os efeitos financeiros da escalada da guerra colonial e do embargo petrolífero a Portugal na sequência da guerra do Yom Kippur. Pela primeira vez, Marcello defrontar-se-á com dificuldades financeiras.

\footnotetext{
${ }^{16}$ Nesta carta, Marcello reconhece que o ânimo de Spínola em relação ao governo não é o melhor, expressando-lhe a vontade de uma "explicação pessoal olhos nos olhos" (CAETANO,1974; 1977; SPINOLA, 1978).
} 
Convém recordar que quando Marcello Caetano assume a chefia do governo, Portugal vive um bom ambiente económico. Sobretudo resultado do efeito EFTA, ${ }^{17}$ Portugal cresce a um ritmo de $6 \%$ do PIB. Devido à crescente onda de emigração e à mobilização para a guerra colonial, dá-se uma redução de 25\% da população ativa, o que originou um período de taxas de desemprego extraordinariamente baixas (2,3\%). Fruto de décadas de políticas de rigor orçamental, de condicionamento industrial, de estabilidade do valor da moeda e de baixo nível de taxas de juro, existia em Portugal uma estrutural estabilidade dos preços (MATEUS, 2006).

Marcello Caetano não irá desbaratar este legado salazarista. Todavia, a sua visão sobre os fins e os meios das políticas económicas era mais ampla e ambiciosa. Marcello acreditava que para além dos aspetos financeiros, o desenvolvimento de Portugal passava por profundas reformas nos sectores das políticas sociais, das políticas industriais, da educação e da agricultura. Por isso, o seu projeto político principal era o de reformar e modernizar globalmente a sociedade portuguesa aproximando-a dos níveis de desenvolvimento europeus. O que, de facto, em termos comparativos com o período anterior, em boa medida, aconteceu.

O período entre 1968 e 1972, designado por alguns economistas como o "quinquénio de ouro" da economia portuguesa, registou uma taxa de crescimento anual de 7,66\%. Uma das taxas mais elevadas do mundo, na altura apenas superada pelas da Grécia e do Japão (PINTADO, 2012; MATEUS, 2006). A par do efeito EFTA, foi o crescimento da emigração ${ }^{18}$, com o consequente aumento de divisas a equilibrar a balança de pagamentos, que contribuíram para o crescimento de Portugal durante as décadas de 1960 e 1970.

Estes fatores externos, foram complementados pelos fatores internos da estratégia desenvolvimentista dos Planos de Fomento (PF) do governo de Marcello. Desde a sua responsabilidade pela coordenação do II PF que Marcello

\footnotetext{
17 A entrada de Portugal na EFTA produziu um forte investimento direto estrangeiro, um aumento do comércio internacional e uma significativa transferência de tecnologia industrial. Entre 1960 e 1973, o valor das exportações portuguesas para a EFTA, em dólares, aumentou 38 vezes. Portugal aumentou exponencialmente a sua produtividade (LOPES, 2004).

${ }^{18}$ Em 1957 a taxa de crescimento anual da emigração era de 0,5\% e o seu valor 34 000. Em 1970 esta taxa foi de 3,6\% e só nesse ano emigraram 180000 portugueses. Em 1973, o número de portugueses em França excedia os 500 000. As remessas de França, que em 1960 representavam 2,5 biliões de francos, atingiram os 11,7 biliões em 1973 (PINTADO, 2012).
} 
tinha a cultura dos PF. Esta cultura dos PF assentava em dois princípios. Primeiro, o desenvolvimento económico do país tinha de se basear no aproveitamento dos seus recursos naturais. Segundo, era essencial pensar estrategicamente o país e estudar, diagnosticar e projetar com rigor para maximizar os recursos humanos e materiais do Estado.

Marcello defendia uma estratégia desenvolvimentista que passava por uma política de progressiva liberalização da economia, da desconstrução do condicionamento industrial e da edificação de importantes infraestruturas. Neste quadro, destaca-se o projeto de Sines. Concebido no quadro do III PF, Sines foi pensado para transformar a paisagem daquela região e ser uma das molas do desenvolvimento de Portugal.

Em 1973, foi ainda aprovado o IV PF para os anos de 1974-1979. Dele constavam o início da construção da barragem do Alqueva em 1974; o início da barragem de Crestuma em 1975; a conclusão, em 1980, da autoestrada do Norte até Braga; a construção de um novo aeroporto na margem sul do Tejo; bem como o objetivo de que a primeira central nuclear em Portugal entrasse em funcionamento no início da década de oitenta (PORTUGAL, 1973).

As suas políticas reformistas alavancaram a modernização da sociedade portuguesa. A começar pelo seu sector mais atrasado. Marcello encetou a primeira tentativa moderna de reforma da desequilibrada estrutura agrária portuguesa. Avançou com uma revitalização do mundo rural tentando criar condições materiais e sociais para o desenvolvimento do interior do país. ${ }^{19}$ Foi com Marcello que teve início uma política integrada de valorização do interior e de tentativa de correção dos desequilíbrios entre o litoral e o interior. Neste quadro, o seu governo propôs a criação dos polos de desenvolvimento regional, nomeadamente os do Nordeste Transmontano, da Cova da Beira, da bacia do Mondego e do complexo de Sines. Outra inovação dos governos de Marcello Caetano foi a criação das seis comissões de Planeamento Regional (PORTUGAL, 1972; 1973).

\footnotetext{
19 A reforma do mundo rural passou pela extensão do regime de previdência aos trabalhadores rurais e pela expansão da rede das Casas do Povo que atingiu os 100\% do território. Entre 1970 e 1973 foram criadas 360 Casas do Povo, que garantiram o processamento das prestações sociais e a articulação com as caixas de previdência. Outro exemplo foi a recriação do Ministério da Agricultura em março de 1974, extinto em 1941.
} 
As reformas sociais da governação de Marcello originaram um avanço significativo da taxa de cobertura da população portuguesa pelo Sistema de Previdência Social. Inicia o seu governo com uma cobertura da segurança social da população ativa de cerca de 38\% e termina-o com uma taxa próxima dos de 90\% (CRUZ, 2012). Foi com Marcello Caetano que pela primeira vez os idosos que nunca tinham feito descontos passaram a receber um pequeno apoio do Estado. Também foi neste período que se iniciaram e sistematizaram vários apoios sociais: o abono de família; assistência na doença; subsídio de nascimento e aleitação; e subsídio de casamento.

Na educação, sob a liderança de Veiga Simão, procedeu-se a uma pioneira reforma do ensino. As suas ideias inspiradoras foram a democratização da educação e da cultura e partiam de uma visão estratégica: "um cidadão mais culto é um cidadão mais livre" (SIMÃO, 2012, p. 377). Acabou-se com o carácter autoritário da Mocidade Portuguesa e introduziu-se uma restruturação global e integrada nas políticas de juventude, cultura, educação e ciência. Com a reforma educativa (lei n.․ 5/73) ficou consagrado o direito à educação; o ensino básico obrigatório e gratuito de oito anos; a democratização da educação associada à igualdade de oportunidades, o acesso pelo mérito e a liberdade de ensino. No ensino superior, através do decreto-lei n. 402/73, são criadas as Universidades do Minho, de Aveiro, a Nova de Lisboa, o Instituto Universitário de Évora; os Institutos Politécnicos da Covilhã, de Tomar, de Faro, de Leiria, de Vila Real e de Setúbal; as Escolas Normais Superiores de Castelo Branco, Viseu, Funchal, Guarda, Bragança, Ponta Delgada, Portalegre e Beja; e a Universidade Católica obteve o seu reconhecimento oficial.

Entre 1968 e 1973, Marcello conseguiu aumentar os índices de desenvolvimento económico de Portugal. Todavia, como sublinha João Salgueiro, era um desenvolvimento insustentável devido aos bloqueios políticos (SALGUEIRO, 2012). Finalmente, e talvez principalmente, o fim do quinquénio de ouro e o início de uma crise económica punham a nu a insustentabilidade da guerra, as fragilidades do projeto económico português e as contradições sociais e laborais existentes, minando qualquer esperança de sucesso da renovação na continuidade. 
O ano de 1973 será decisivo. Para além da crescente agitação e radicalização da oposição, Marcello vai perder o apoio dos liberais e tecnocratas, aprofundar a desconfiança dos ultras e abrir uma nova frente de conflito com os militares, o que lhe será fatal. Ano de eleições, 1973 será fértil em movimentações políticas, com praticamente todas as forças sociais e políticas a marcarem o seu terreno. A oposição clássica realiza o seu terceiro congresso em Aveiro, entre os dias 4 e 8 de Abril. Com centenas de comunicações, este foi o maior Congresso da Oposição Democrática. Em Aveiro sobressaiu uma crescente esquerdização do discurso político da oposição e uma assunção clara de rotura com o governo.

A 4 de maio, o cardeal patriarca de Lisboa, D. António Ribeiro, publica a "Carta pastoral no décimo aniversário da Pacem in Terris", onde introduz um inovador discurso sobre "os direitos humanos fundamentais", nomeadamente o “direito à participação político-social" e à necessidade do "reconhecimento efetivo do pluralismo legítimo" (CEP, 1978, p.119-123). Numa clara alusão ao processo eleitoral, a Igreja portuguesa sublinha que é fundamental que "haja participação consciente dos cidadãos aos quais cabe o direito de sufrágio" e para este se cumprir de forma efetiva, "deve poder exercer-se livre e ordenadamente" (CEP, 1978, p.119-123). Também a Igreja começava a marcar uma posição sobre a necessidade de uma evolução democrática.

Em Tomar, no dia 6 de Maio, Marcello discursa no encerramento do congresso da Ação Nacional Popular (ANP). Para além de justificações laudatórias à ação do governo, da reafirmação da renovação na continuidade e da narrativa maniqueísta, Marcello ensaia uma ideia muito própria do momento político de 1973. Para Marcello o seu governo não é de direita nem de esquerda. O governo situa-se no centro da virtude política, pois só ele consegue de forma pragmática resolver os problemas do país (PORTUGAL, 1973; CAETANO, 1973a). Marcello tinha uma certa razão, uma vez que para além da tradicional oposição à sua esquerda, a democrática e a radical, existia também uma oposição de direita integracionista e anti-marcelista. Esta ultradireita organizará um encontro a 1 de junho, no Porto, o "Congresso dos Combatentes do Ultramar", com o objetivo de demonstrar o peso da corrente integracionista através da voz avalizadora dos combatentes, defensores do Portugal multicontinental. 
Entre os dias 28 e 29 de julho, realiza-se o congresso dos liberais em Lisboa. Este "Encontro de Reflexão Política", organizado pelos deputados Magalhães Mota, Oliveira Dias e José da Silva, teve uma grande participação e, para além de uma clivagem ideológica com o governo, foi também reflexo de um debate geracional contra a gerontocracia rotativa do Estado Novo (MENDES, 2012; 2013). Apesar das suas diferenças ideológicas e políticas, é paradigmático notar que em todos estes encontros existe um ponto de reflexão comum: a questão ultramarina e a guerra colonial.

O crescimento económico e as reformas sociais foram um sustentáculo do governo de Marcello nos primeiros anos, a continuação da guerra obscurecia os resultados obtidos e minava o regime. Mais do que as dificuldades da estratégia militar no terreno das operações, o problema foi a estratégia política da gestão da guerra. Embora interligadas, a principal contrariedade resultou da má gestão política das reivindicações militares. ${ }^{20}$

Em agosto, Marcello começa a pensar na elaboração das listas de deputados às eleições marcadas para outubro. O seu estado anímico não é o melhor. Marcello sente-se cansado e politicamente abandonado. Chega mesmo a desabafar com Freitas de Amaral que "se as Forças Armadas, que são fiadoras da integridade da pátria, não quiserem continuar a guerra e entenderem dever tomar o poder para acabar com ela, eu de bom grado tho cederei. Só espero que não me metam na cadeia por thes fazer a vontade" (AMARAL, 1995, p. 127-130).

Prestes a completar cinco anos de governo e com novas eleições para a Assembleia à porta, Marcello encontra-se isolado. Os difíceis equilíbrios políticos entre as várias correntes do regime que tinham permitido a sua ascensão ao poder estão desfeitos. Neste período, como recorda a sua filha, Ana Caetano, o Presidente do Conselho "parecia uma itha rodeada de oposição por todos os lados" (CASTANHEIRA, 2009). De acordo com Ana Caetano - que, como primeiradama substituta, viveu de perto o ambiente política da época - Marcello "teve o condão de não agradar a ninguém" (CASTANHEIRA, 2009).

\footnotetext{
20 Tudo começa na contestação dos oficiais intermédios ao decreto-lei n.o 353/73. Promulgado a 13 de julho, permitia a passagem dos oficiais milicianos ao quadro permanente. Apesar da posterior emenda de 20 de agosto (decreto-lei n. 409/73), a contestação alastrou-se à metrópole e a todas as frentes de guerra.
} 
Em 27 de Setembro, Marcello completa cinco anos de governo e dirige-se ao país em mais uma Conversa em Família. Fala da sua ação governativa, da importância das eleições que se aproximam e repete o discurso maniqueísta. Os eleitores estão perante "opções decisivas": "ou continuar um regime que em tantos aspetos se tem revelado adaptado às necessidades do país, ou implementar outro a caminho do desconhecido" (CAETANO, 1973b, p. 12).

Neste período, todavia, a grande opção passava por resolver a contestação militar liderada pelos oficiais intermédios. Marcello pensou em aplicar processos disciplinares aos contestatários, mas logo percebeu que não era possível fazer isso a centenas de oficiais. O movimento dos capitães contacta o general Costa Gomes, que vai falar diretamente com Marcello sobre a injustiça que se abate sobre os oficiais do quadro permanente. Marcello não gostou desta intromissão do Chefe de Estado-Maior General das Forças Armadas (CEMGFA) e sobretudo da sua posição de defensor e porta-voz de um movimento de militares. Na sua opinião, um governo, ainda por cima em guerra, não podia permitir a indisciplina e a contestação aberta de um grupo militar.

Numa conversa tensa com Costa Gomes, Marcello chega mesmo a admitir que se existe insubordinação militar e que se o general achava que a solução passava pela assunção do poder das Forças Armadas ele entregaria o poder. Costa Gomes responde que não era isso que estava em causa, mas sim a resolução de um grave problema de injustiça e de desprestígio dos militares do quadro permanente. Marcello replica que o movimento reivindicativo teria de cessar para que o governo pudesse livremente debruçar-se sobre o assunto. A conversa terá tido o seu epílogo com Costa Gomes a questionar sobre quanto tempo necessitaria o governo para resolver o problema, ao que Marcello terá respondido: "quinze dias, três semanas" (CAETANO, 1974, p. 187-188).

Quando parece impossível a situação piorar, no dia 6 de outubro rebenta a guerra de Yom Kippur. No dia 13, o Presidente Nixon envia um ultimato a Marcello, que não tem outra opção senão aceitar o pedido urgente dos EUA. O uso das Lages desencadeou um movimento de hostilidades do mundo árabe em relação a Portugal na ONU e na OPEP. Portugal vai sentir os efeitos da crise petrolífera consequente e, no dia 28 de novembro, os chefes de Estado árabes 
anunciam o embargo petrolífero a Portugal. Após o surgimento da inflação, o embargo petrolífero de 1973 provocam sérios problemas, designadamente restrições ao consumo de gasolina.

No dia 28 de outubro, realizam-se as eleições para a Assembleia Nacional. Ao contrário do ambiente de esperança que precedeu as eleições de 1969, agora o ambiente era de impasse. As eleições de 1973 não trouxeram nada de novo que permitisse desanuviar o bloqueio político com que o regime se defrontava. Marcello não conseguiu que se formassem forças alternativas ou dissidentes nas listas da ANP, nem mesmo que se oficializasse uma terceira via. A oposição clássica aproveitou a campanha para questionar a política ultramarina e demonstrar o ambiente repressivo do governo. Em consequência, desistiu em bloco alegando falta de condições mínimas. Na verdade, estas eleições refletem bem o estado anacrónico a que o regime do Estado Novo tinha chegado. Não foram um momento fulcral de debate sobre as decisões políticas para o futuro do país, antes representaram um instrumento político, quer do governo, quer da oposição. Marcello queria eleições participadas e que as candidaturas da oposição não desistissem para provar a sua pretensa legitimidade democrática, a oposição queria as eleições para provar que existia repressão e nenhuma legitimidade democrática no processo eleitoral.

Apesar de não ser um democrata e ter as maiores reservas sobre a implantação de um regime democrático pluripartidário em Portugal, Marcello percebia que os líderes políticos deveriam ter um qualquer tipo de legitimidade democrática. Daí a sua constante menção ao "mandato indeclinável"(CAETANO, 1970) que recebera do povo português em 1969 (VALENTE, 2002). Este sempre foi um dos principais paradoxos da personalidade política de Marcello. Ele desejava, e precisava, ter legitimidade democrática, por isso insistia em eleições participadas e corretas. Todavia, tinha receio de perder o controlo dos acontecimentos se possibilitasse uma abertura verdadeiramente livre e democrática.

Após as eleições, em 7 de novembro, Marcello fará outra remodelação governamental. Diferentemente da anterior, centrada na vertente económica, esta tem uma clara orientação política. É a tentativa de Marcello formar um 
governo de combate político com base em homens de confiança pessoal. Marcello tenta ainda patrocinar uma associação política no âmbito da ANP, que agruparia jovens de direita moderada, muitos dos quais viriam a fundar o Centro Democrático Social (CDS). Aqui, destaca-se Adelino Amaro da Costa que foi incumbido por Silva Pinto de redigir o programa da associação. Seria composta por marcelistas do governo e da sociedade civil, uma espécie de SEDES ${ }^{21}$ de centro-direita.

Talvez aqui estivesse, finalmente, o seu grupo fiel de apoio que the permitisse ultrapassar o "vácuo" político onde acabou por se colocar (VALENTE, 2002), mas também esta ideia não foi aproveitada a tempo e acabou por se perder. Nas vésperas do 25 de Abril de 1974, a associação realizava a sua primeira reunião e contava com cerca de quarenta membros fundadores. É provável que o seu programa se interligue com a fundação do CDS. Também é provável que um partido de direita, cristão e social fosse um partido a que Marcello pudesse pertencer. Convém notar, todavia, que tal como aconteceu com a SEDES, Marcello não resistiu à tentação de controlar a associação e insistiu para que a maioria dos membros da sua direção fossem filiados na ANP.

Como é usual nos políticos intelectuais, Marcello tinha uma excecional capacidade analítica e lia bem os cenários prováveis do que podia acontecer, a sua maior dificuldade prendeu-se com a definição - e o timing - das soluções a adotar. O seu problema foi que face às tensões crescentes da sociedade portuguesa, em vez de possibilitar uma abertura que as acomodasse, a sua solução foi sempre no sentido de as tentar limitar e controlar. E aqui emerge um

\footnotetext{
${ }^{21}$ A SEDES (Associação para o Desenvolvimento Económico e Social) nasce em 1970 como "associação civil" independente da ANP. Era composta por jovens técnicos, advogados e jornalistas. Inicialmente apadrinhada por Marcello e inserida na alegada política de renovação, mas rapidamente se distanciou da efetiva continuidade seguida por Marcello. Foram 147 os peticionários da licença para a fundação da SEDES; entre estes contavam-se Miguel Caetano, filho de Marcello, dois governantes, Rogério Martins e Xavier Pintado, e seis deputados da Assembleia Nacional: Pinto Leite, Joaquim Pinto Machado, Joaquim Macedo, Alberto Lobo e Silva e Magalhães Mota. Todavia, a grande maioria dos fundadores eram quadros técnicos, de onde podemos destacar o papel de 22 engenheiros e 15 economistas contra apenas 14 advogados, formação com uma posição tradicionalmente dominante na política portuguesa. De um ponto de vista ideológico as referências da SEDES eram variadas e iam desde o liberalismo, passando pela social-democracia, até ao marxismo. Sobre o papel da SEDES cf. MENDES (2012; 2013; 2020a), ver ainda a opinião de Marcello sobre a criação da SEDES e dos seus "infiltrados" (CAETANO, 1974, p. 67-68).
} 
dos famosos erros dos decisores: a convicção de que a sua perceção racional sobre determinado problema é a solução mais eficiente.

Nestes casos, como com Marcello, está ausente a humildade democrática de compreender que mesmo racionalmente correta, do ponto de vista do governante, uma solução política pode não ser viável face à perceção de ilegitimidade dos governados. Marcello desejava que os portugueses entendessem e aceitassem a sua visão, mas a maioria da sociedade, designadamente os mais jovens e politizados, já não compreendia nem queria a sua visão.

Marcello percebeu que a radicalização das oposições, à direita e à esquerda, estava a contagiar a sociedade, mas falhou na sua solução racional de controlo autoritário que, ao contrário do pretendido, aumentou o apelo radical. A partir de meados de 1973, várias faculdades das Universidades de Lisboa e Porto transformam-se em "centros revolucionários" e no mundo do trabalho irão suceder-se greves sem precedentes. As condições económicas e sociais deterioram-se. Todavia, Marcello pressente que o maior problema é a agitação no meio militar. Por isso, embora contrariado, Marcello acaba por ceder às pressões e, no dia 24 de dezembro, são publicados quatro diplomas com o intuito de aplacar a contestação militar. ${ }^{22}$

O ano político de 1974 inicia-se com a tomada de posse do general Spínola no seu novo cargo, certamente uma forma de o comprometer com o governo, limitando-lhe a margem de manobra para uma contestação aberta. O que, apesar de tudo, acabou por não acontecer devido à publicação do seu livro Portugal e o Futuro. O livro teve um grande impacto e provocou um pequeno terramoto político. O livro defendia ideias que implicavam a democratização do regime, a aproximação à CEE, o reconhecimento do princípio da autodeterminação, a necessidade do fim da guerra e de uma solução política (federalista) para as

\footnotetext{
22 O primeiro cria o cargo de vice CEMGFA destinado ao general Spínola; o segundo cria dez vagas para coronel nos quadros de Infantaria, Artilharia e Cavalaria; o terceiro repôs a exigência da frequência do curso normal da Academia Militar para ingressar na carreira militar do quadro permanente, revogando os decretos 353/73 e 409/73; o quarto determinou as possibilidades de promoção dos oficiais milicianos que quisessem seguir a carreira militar até ao posto de coronel. Passados oito dias o governo aprovou a maior atualização salarial das Forças Armadas.
} 
colónias. A publicação do livro foi interpretada como um verdadeiro manifesto contra o governo e representou uma bandeira política para o movimento dos capitães. Marcello sente o chão a fugir, pede uma audiência a Américo Tomás, que o recebe no dia 28, e põe o seu lugar à disposição. Tomás recusa a exoneração de Marcello e mantém a confiança no chefe de governo. Concordaram que a solução passaria por "procurar, pelos meios constitucionais, obter a expressão da vontade da nação e, de acordo com ela, proceder então" (CAETANO, 1974, p. 198).

A solução encontrada foi a de ensaiar uma legitimação da política ultramarina do governo junto da Assembleia Nacional. No dia 5 de março, Marcello Caetano comparece perante os deputados para realizar um decisivo discurso, intitulado "Reflexões sobre o Ultramar". No final, foi apresentada e posta à consideração dos deputados uma moção da Comissão do Ultramar que apelava à aprovação do rumo traçado pelo governo relativamente à política ultramarina. Após a discussão, em 8 de março, a Assembleia Nacional aprova por unanimidade e aclamação a moção de apoio à política ultramarina do governo (MENDES, 2020a).

Com este novo sopro de legitimidade política, Marcello reúne com o Presidente da República no dia 11 de março para discutir a nova proposta de remodelação do sector económico do seu governo. Nesta reunião, Marcello terá tido a mais complexa e difícil conversa com Américo Tomás (CASTILHO, 2012), que foi altamente crítico quanto à forma como Marcello tinha deixado que a situação política se descontrolasse. Marcello sai da reunião agastado e escreve uma carta ao Presidente da República onde admite os seus erros e propõem a sua exoneração. Apesar das críticas, Américo Tomás não aceita a demissão de Marcello e renova tacitamente a sua confiança no chefe do governo. Contudo, opina que os generais Costa Gomes e Spínola não deveriam passar incólumes.

Marcello põe em marcha um plano de legitimação do seu poder junto dos militares e reúne no dia $12 \mathrm{com}$ os ministros das pastas militares para lhes expor o plano e obter a sua concordância. A ideia era a de testar a fidelidade de Costa Gomes e de Spínola pedindo-lhes que comparecessem junto do Presidente do Conselho, juntamente com todos os oficiais-generais em serviço na metrópole, 
para declararem que as Forças Armadas não tinham política própria e que cumpririam, por dever ético e de função, a política definida pelo governo. Marcello estaria disposto a manter os generais no seu posto se Costa Gomes, tendo a seu lado Spínola, fizesse essa declaração solene. Nesse mesmo dia, em reunião do Gabinete de Defesa Nacional, o ministro da Defesa formulou o pedido a Costa Gomes, que prontamente se recusou a fazer a declaração solicitada. Perante a atitude do general, que teve a solidariedade de António Spínola e do contraalmirante Tierno Bagulho, foi convidado a falar o mais antigo dos chefes dos Estados Maiores, o general Paiva Brandão.

Conforme combinado, no dia 14 de março, Marcello ensaia uma tentativa de renovação da aliança entre o seu governo e as Forças Armadas. Encena-se uma reunião com um vasto conjunto de generais no Palácio de São Bento que ficou conhecida como a brigada do reumático. Trata-se de uma manifestação de apoio público das chefias militares a Marcello Caetano e à defesa da política ultramarina que pretende dar um sinal de normalidade e unidade entre o governo e as Forças Armadas. Após o discurso de Paiva Brandão, que inclui a declaração solicitada, Marcello realiza o discurso "As Forças Armadas têm a política da Nação", onde afirma:

"O chefe do governo escuta e aceita a vossa afirmação de lealdade e disciplina. A vossa afirmação de que as Forças Armadas não só não podem ter outra política que não seja a definida pelos poderes constituídos da República, como estão, e têm de estar com essa política" (CAETANO, 1974, p. 202).

Nesse mesmo dia, Marcello faz um despacho que demite os generais Costa Gomes e António Spínola dos respetivos cargos de chefe e vice-chefe do CEMGFA. No dia seguinte, 15 de março, procede à sua última remodelação ministerial. Ainda nessa noite, Marcello recebe um telefonema do ministro da Defesa a comunicar que algo se passava em certos quartéis e na Academia Militar. Já no dia 16 de março é informado que existe um levantamento de militares do Regimento de Infantaria n. 5, nas Caldas da Rainha. A tentativa de golpe não teve sucesso, pois não estava articulado com um plano nacional rigoroso de operações, o que viria a acontecer no dia 25 de Abril. Todavia, era um sinal claro da ansiedade que se vivia nos quartéis. 
Para Marcello a lição a retirar foi a de que perante um ato de insubordinação militar o governo reagiu de forma exemplar. Na sua opinião, "o êxito do governo foi total" (CAETANO, 1977, p.38) e, apesar das medidas de controlo que se instalaram, a nota oficial que o governo emite às 18 horas do dia 16 acaba com a frase anacrónica, típica do Estado Novo, "Reina a ordem em todo o país" (CASTILHO, 2012, p. 815).

Após a renovação da confiança política do Presidente da República, do apoio público da Assembleia Nacional e dos militares, Marcello está convencido que, apesar das dificuldades, tem a situação controlada. Nesse espírito, envia uma carta ao seu amigo Lopez Rodó, no dia 20 de março, onde escreve: "Tenho vivido dias difíceis, mas que graças ao apoio do povo português e à fidelidade das Forças Armadas fui vencendo" (ANTUNES, 1985, p. 294).

Do mesmo modo, na sua última Conversa em Família na RTP, em 28 de março, apesar de cansado e tenso, Marcello faz um discurso onde tenta dar uma imagem de que ainda mantinha o controlo da situação e que não permitiria o abandono dos portugueses no ultramar.

A verdade, porém, é que, sobretudo a partir de 1973, o governo passou a viver num estado de permanente encenação política, típica dos regimes autoritários acossados com o fim à vista. Isto significou que a vida política em Portugal era dominada por um ambiente político esquizofrénico. Por um lado, na vida da corte, o governo continuava a governar em estado de negação, mantendo a política usual de que tudo estava sob controlo, contrariando tudo e todos que ousavam desdizer a versão oficial dos acontecimentos. Por outro, na vida real, assistia-se ao desmoronamento progressivo do regime. As suas sedes de legitimação iam-se perdendo e o clima antiguerra tinha chegado aos militares. Era o fim da linha.

Às 5 horas da manhã do dia 25 de Abril de 1974, Marcello acorda com um telefonema do diretor da DGS, major Silva Pais, informando-o que "a revolução está na rua! o caso é muito grave" (CARVALHO, 2011, p. 96). 
Já no Quartel do Carmo, após começar a perceber a gravidade da situação, Marcello telefona às 6.45 horas para o ministro do Exército, Andrade e Silva, nos seguintes termos: "Então sr. general, isto é que é o tal movimentozeco sem importância, facilmente controlável?” (CARVALHO, 2011, p. 107). O general argumenta que não existe problema sério e que a situação não tarda a estar controlada, uma vez que estavam a ser tomadas medidas para cercar os revoltos.

Na verdade, era exatamente o oposto e por essa altura já o Movimento das Forças Armadas tinha o controlo da situação. Incrédulo, abandonado e em desespero, Marcello ainda tentou que forças militares fiéis ao governo tentassem um exercício de força contra os revoltosos e a populaça. Mas ninguém considerou verdadeiramente que valia a pena defender o regime, que ruiu como um castelo de cartas.

\section{Conclusão: o governo de Marcello Caetano que balanço?}

Como sempre acontece, importa começar por sublinhar que existem várias dimensões e prismas de análise sobre o legado de um político. Uma coisa é analisar o que Marcello desejaria que acontecesse, outra coisa é analisar o que Marcello pensa que aconteceu, outra coisa, ainda, é analisar o que os outros, críticos e defensores, acham que aconteceu. Finalmente, existe a tentativa de analisar o que, factualmente, aconteceu, tendo presente que na vida política, como na vida em geral, o que acontece é sempre o resultado inelutável do confronto entre o que se deseja fazer e o que nos é possível fazer.

Em segundo lugar, para quem viveu o período marcelista é difícil, para não dizer impossível, não ter uma ideia historicamente influenciada pelas suas preferências e desejos políticos, a começar pelos próprios testemunhos de Marcello, onde parece existir uma contínua necessidade de justificação e de acerto de contas com a História. Dentro deste quadro de análise podemos avançar duas perspetivas sobre o balanço histórico da vida política de Marcello e do seu legado como chefe de governo: a técnica e a política.

De um ponto de vista técnico o governo de Marcello Caetano alcançou importantes reformas sectoriais, nomeadamente no plano laboral, na segurança 
social, na saúde, na educação, na política industrial e investimentos infraestruturais. Em todos estes sectores se assistiu a novas e reformistas políticas públicas. É com Marcello que se inicia a substituição do paradigma do sistema económico e social português. Ou seja, se inicia a transição de um Portugal rural, atrasado, tradicional e autárcico, para um Portugal relativamente urbano, desenvolvido, moderno e incipientemente europeizado.

Apesar das normais adaptações sistémicas e choques exógenos, no longo curso, uma análise eminentemente técnica das linhas programáticas governativas da democracia portuguesa revela que existe uma espantosa continuidade relativamente às principais ideias estratégicas de modernização e desenvolvimento dos governos de Marcello. Não é de admirar, portanto, que grande parte da geração de "homens novos", tecnocratas e reformistas, que trabalhou com Marcello no governo e nos Planos de Fomento integrem os partidos do arco da governação tradicional (PS, PSD e CDS) e desempenhem relevantes funções públicas no período democrático.

No plano político, porém, Marcello Caetano não conseguiu ultrapassar os obstáculos que condicionavam a sua ação, a começar pela reforma do aparelho político. Apesar de ter introduzido pessoas novas e independentes no Governo e na Assembleia Nacional, não foi capaz de sustentar as suas posições políticas mais avançadas, enfrentar a elite salazarista e caminhar para uma democratização.

Ao nível da sociedade civil, quer no sector progressista da Igreja Católica, quer na oposição de esquerda moderada, não conseguiu desenvolver as pontes iniciais e construir um diálogo político que possibilitasse conduzir o regime a uma transição pactuada em Portugal. Marcello foi perdendo sucessivamente os principais testes de fogo e desperdiçou todas as oportunidades políticas para introduzir mudanças substâncias e não apenas mudanças cosméticas de reformulação das designações e de burilamento jurídico dos condicionamentos autoritários do Estado Novo.

Marcello perde sucessivamente as oportunidades das eleições de 1969, da revisão constitucional de 1971 e, finalmente, da eleição presidencial em 1972 para introduzir verdadeiras mudanças no regime. Ao não conseguir aproveitar estas 
oportunidades vai perder os apoios da oposição democrática não comunista, da Ala Liberal e de muitos marcelistas e independentes que acreditavam na inevitabilidade da mudança do regime político. Perdidos estes apoios, Marcello foi ficando cada vez mais isolado e refém dos defensores continuistas do regime autoritário. O que aumentou a frustração dos que acreditaram nas virtualidades do marcelismo, ampliou o radicalismo da oposição esquerdista e encurralou Marcello numa continuidade autoritária que não tinha possibilidades de ultrapassar os estrangulamentos políticos do regime.

Em abono de Marcello, pode-se dizer que a conjuntura que herdou era difícil e o problema colonial condicionava bastante as escolhas políticas. Ou ainda, como o próprio e muitos dos seus próximos sublinham, Marcello precisaria de mais tempo, pois o seu projeto de liberalização e reforma da sociedade portuguesa teria um horizonte de 10 a 15 anos. Todavia, como o tempo veio a demonstrar, com o passar do tempo, desde 1970 até 1974, não se realizaram progressos na liberalização política. Bem pelo contrário, com o passar do tempo, acentuaram-se as contradições político-autoritárias do regime e a radicalização da sua contestação.

Claro que numa visão contra factual eficiente da história se pode facilmente extrapolar que teria sido preferível uma transição pactuada em Portugal. Esta transição poderia ter possibilitado a manutenção do ritmo de crescimento económico sem os cortes revolucionários do Período Revolucionário em Curso (PREC). Todavia, pensar assim é ingénuo e cientificamente pouco rigoroso, pois conduz ao caminho da relativização da compreensão histórica e da negação das causas e dos motivos que fundamentam os seus processos.

Em síntese, de um ponto de vista estritamente técnico, Marcello, para além de um académico de mérito, foi um chefe de governo com inegáveis qualidades de trabalho e de coordenação técnica, tendo lançado importantes reformas sectoriais. O seu governo conseguiu aumentar os índices de desenvolvimento económico de Portugal. Contudo, foi um desenvolvimento relativamente artificial e insustentável devido aos constrangimentos políticos que não foram ultrapassados. Deste modo, de um ponto de vista político, Marcello acabou por ser um fracasso. 


\section{Referências}

AMARAL, Diogo, Freitas. O antigo regime e a revolução: memórias políticas (1941-1975). Vendas Novas: Bertrand, 1995.

ANTUNES, José Freire. (org.). Cartas particulares a Marcello Caetano. Lisboa: D. Quixote, 1985. 2. v.

BALSEMÃO, Francisco, Pinto. A terceira via. In: CRUZ, M. B. e RAMOS, R. (org.). Marcello Caetano tempos de transição. Porto: Porto Editora, 2012, p.167-177.

CAETANO, Marcelo. Mandato indeclinável. Lisboa: Verbo, 1970.

CAETANO, Marcelo. Renovação na continuidade, Lisboa, Verbo, 1971.

CAETANO, Marcelo. Progresso em paz, Lisboa: Verbo, 1972a.

CAETANO, Marcelo. Pela Segurança, Bem Estar e Progresso do Povo Português! Lisboa: SEIT, 1972b.

CAETANO, Marcelo. As grandes opções. Lisboa: Verbo, 1973a.

CAETANO, Marcelo. Na véspera das eleições. Lisboa: SEIT, $1973 b$.

CAETANO, Marcelo. Depoimento. Rio de Janeiro: Record, 1974.

CAETANO, Marcelo. O 25 de Abril e o Ultramar: três entrevistas e alguns documentos. Lisboa: Editorial Verbo, 1977.

CARNEIRO, Francisco, Sá. Textos 2o volume (1973-1974). Lisboa: Aletheia, 2010.

CARVALHO, Otelo, Saraiva. O dia inicial. Lisboa: Objectiva, 2011.

CASTANHEIRA, José, Pedro. Marcello Caetano foi um homem excepcional. Expresso. Lisboa, 14 de fevereiro, 2009. Disponível em:

ttps://expresso.pt/dossies/dossiest_actualidade/dossie_marcelo_caetano_a_tra nsicao_falhada/marcelo-caetano-foi-um-homem-excepcional=f497770 Acesso em: 13 Março de 2018.

CASTILHO, José, Tavares. Marcello Caetano: uma biografia política. Coimbra: Almedina, 2012. 
CEP, Conferência Episcopal Portuguesa. Carta pastoral no décimo aniversário da Pacem in Terris. In: Documentos pastorais: 1967-1977. Lisboa: União Gráfica, 1978, pp. 119-123.

CRUZ, Ivo. Segurança Social. In: Cruz, M. B. e Ramos, R. (org.). Marcello Caetano: tempos de transição. Porto: Porto Editora, 2012. p. 425-430.

CRUZ, Manuel, Braga; RAMOS, Rui. (org.). Marcello Caetano: tempos de transição. Porto: Porto Editora, 2012.

CUNHA, J. M. S. O ultramar, a nação e o 25 de Abril. Coimbra: Atlântida, 1977.

LEITÃO, Luís, Menezes. Marcello Caetano: um destino. Lisboa: Quetzal Editores, 2014.

LOPES, José, Silva. A economia portuguesa no século XX. Lisboa: Imprensa de Ciências Sociais, 2004.

LUCENA, Manuel. A evolução do sistema corporativos português: O Marcelismo. Lisboa: Perspectivas e Realidades, 1976. v. 2.

MATEUS, Abel. Economia Portuguesa. Lisboa: Verbo, 2006.

MENDES, Pedro Emanuel. A dimensão internacional da transição democrática em Portugal: a influência da Europa. População e Sociedade, Porto, n.11, p. 171192, 2004.

MENDES, Pedro Emanuel. Portugal e a Europa: factores de afastamento e aproximação da política externa portuguesa (1970-1978). Porto: CEPESE, 2012.

MENDES, Pedro Emanuel. A questão europeia no marcelismo: o debate geracional. População e Sociedade, Porto, n. 21, p. 107-121, 2013.

MENDES, Pedro Emanuel. Identidade, ideias e normas na construção dos interesses em política externa: o caso português, Análise Social, Lisboa, 227, LIII (2), p. 458-487, 2018.

MENDES, Pedro Emanuel. História, discurso político e liderança em Portugal: um diálogo interpretativo entre presente e passado à luz do Diário de Governo.

População e Sociedade, Porto, n. 32, p. 182-203, 2019.

MENDES, Pedro Emanuel. Marcelo Caetano. In: SOUSA, Fernando; MEIRELES, Conceição. Os primeiros ministros de Portugal. Lisboa: Imprensa Nacional Casa da Moeda, 2020a. 
MENDES, Pedro, Emanuel. Percepções e imagens na política externa do Estado Novo: a importância do triângulo identitário. Dados: Revista de Ciências Sociais, Rio de Janeiro, v. 63 n. 3, 2020 b.

O'DONNELL, Guillermo; SCHMITTER, Philippe. Defining some Concepts. In: O'DONNELL, Guillermo; SCHMITTER, Philippe C; WITEHAED, Laurence (ed.). Transitions from authoritarian rule: prospects for democracy. Baltimore: The Johns Hopkins University Press, 1986.

PEREIRA, André, Gonçalves.; MIRANDA, J. e TELES, M. G. Debate sobre a revisão constitucional de 1971. In: Cruz, M. B. e Ramos, R. (org.). Marcello Caetano tempos de transição. Porto: Porto Editora, 2012. p.181-201.

PINTADO, Xavier. O quinquénio dourado. In: Cruz, M. B. e Ramos, R. (org.), Marcello Caetano tempos de transição. Porto: Porto Editora, 2012, p. 345-353.

PORTUGAL. Segundo do ano de acção do governo de Marcello Caetano. Lisboa: SEIT: DGI, 1970.

PORTUGAL. Portugal, Terceiro ano de acção do governo de Marcello Caetano. Lisboa: SEIT: DGI, 1971.

PORTUGAL. Governo de Marcello Caetano: quarto ano de actividade. Lisboa: SEIT: DGI, 1972.

PORTUGAL. Quinto ano do governo de Marcello Caetano. Lisboa: SEIT: DGI, 1973.

RAMOS, Rui. Nossas Memórias de Marcelo Caetano. (Ensaio para uma análise histórica). In: Cruz, M. B. e Ramos, R. (org.). Marcello Caetano: tempos de transição. Porto: Porto Editora, 2012. p. 465-506.

ROSAS, Fernando. O Estado Novo, história de Portugal. Lisboa: ediç,ões Estampa, 1994.v. 7.

ROSAS, Fernando. O marcelismo ou a falência da política de transição no Estado Novo. In: BRITO, J. M. B. (coord.) Do marcelismo ao fim do império. Lisboa: Notícias, 1999, p. 15-59.

SALGUEIRO, João. Um Sucesso Insustentável. In: Cruz, M. B. e Ramos, R. (org.). Marcello Caetano tempos de transição. Porto, Porto Editora, 2012, p. 79-86.

SIMÃO, Veiga. Educação em Mudança. In: Cruz, M. B. e Ramos, R. (org.). Marcello Caetano tempos de transição. Porto: Porto Editora, 2012, p. 373-400.

SOARES, Mário. Escritos do exílio. Lisboa: Bertrand, 1975. 
SPÍNOLA, António. País sem rumo. Lisboa: SCIRE, 1978.

TORGAL, Luis Reis. Marcelismo, "Estado Social" e Marcello Caetano. In: ESTADOS NOVOS, ESTADO NOVO. Coimbra: Imprensa da Universidade de Coimbra, 2009, p. 615-673.

VALENTE, Vasco, Pulido. Marcello Caetano: as desventuras da razão. Lisboa: Gótica, 2002. 